\title{
Work-related ill-health in construction: the importance of scope, ownership and understanding
}

\begin{abstract}
Work-related ill-health in construction is a major concern worldwide, presenting significant risk management challenges. This three-year research project studied a multi-million pound regional construction project and a multi-billion pound infrastructure megaproject in the UK. It used interviews $(n=237)$ and meeting observations $(n=120)$ to examine contemporary approaches to managing occupational health in the industry and their limitations. It was found that the conceptualisation of 'health' is a significant issue: activities which focus on the general health and wellbeing of the workforce can distract from the reduction of work-related hazards at source. There are further challenges in the way health risk is perceived and tolerated by workers and organisations. This is partly because of the invisibility and latency of the associated health effects, but also reflects incomplete knowledge and a sense of resignation. Crucially, there is evidence of a lack of ownership of health within organisations and on the part of some managers, frontline workers and OSH professionals. These aspects are exacerbated by the way in which the construction industry operates, with high levels of self-employment and worker mobility; the temporary nature of projects which inevitably foregrounds immediate safety concerns over longer term health issues; and the cost of and limited access to health services. Health risks are challenging to manage because 'health' differs from 'safety'; in terms of the hazards themselves but also in the way that the construction sector understands and manages risk. These differences need to be recognised and addressed to achieve lasting improvements to worker health in construction.
\end{abstract}

Keywords: construction; occupational health; work-related; ill-health, H\&S management 


\section{Introduction}

Work-related ill-health is a major concern in construction. In the UK, there are around 4,000 health-related worker deaths each year (compared to an average of 39 who die as a result of accidents) and 80,000 people suffering impairment (HSE, 2018a). Deaths are predominantly from cancers, particularly those related to asbestos exposure; respiratory diseases such as silicosis and COPD (chronic obstructive pulmonary disease) are also prevalent. The pattern is mirrored internationally. The prevalence of cancers, respiratory diseases, musculoskeletal disorders (MSDs) and noise-induced hearing loss (NIHL) are disproportionately high across the construction sectors of many countries in Europe and worldwide (Arndt et al., 2005, Stocks et al., 2010, 2011, Boschman et al., 2011, Quinn et al., 2014, van der Molen et al., 2016, West et al., 2016, Biswas, Bhattacharya and Bhattacharya, 2017, Borup et al., 2017, Wang et al., 2017).

The impact of these diseases is considerable. In the UK for example, construction-related cancers cost society (including workers, employers, and government) f189 million per annum (HSE, 2016). Other workrelated conditions cost even more: an estimated $f 848$ million each year for employers (Gibb, Drake and Jones, 2018), and as much as four times this amount to individuals and society (HSE, 2018b). Additionally, those suffering from work-related ill-health will experience substantial personal impact and reduced quality of life associated with conditions such as COPD (Svedsater et al., 2016, Franssen et al., 2018), HAVS (hand arm vibration syndrome) (Le, Ay and Ayers, 2010, Handford et al., 2017, Budd, Holness and House, 2018), tinnitus (Hall et al., 2018), dermatitis (Diepgen, 2003) and back pain (Froud et al., 2014).

Work-related health conditions can be challenging to address for several reasons. First, there is the long latency of many conditions. For example, cancers caused by asbestos are typically identified around 30 years after first exposure and may occur up to 60 years later (Frost, 2013, Sen, 2015). Other conditions, such as silicosis, may take 10-20 years to develop (Pérez-Alonso et al., 2014, Mazurek et al., 2017), likewise HAVS, although this can be highly variable depending on the level of exposure (NIOSH, 1989, Falkiner, 2003). Because of this time lag, improvements in prevalence may only come many years after reduction in exposures. The long interval can also obscure the link between cause and effect, with implications when trying to persuade workers of the importance of changing their behaviour. Additionally, it makes it difficult to attribute employer responsibility for illness, reducing the financial incentive for companies to take preventative action, particularly if this is deemed to be costly.

Other conditions may have shorter latency but still be difficult to associate clearly with particular exposures. Linking cause and effect can be a substantial challenge for mental health conditions (Marchand and Blanc, 2010) and MSDs (Kwon et al., 2011, Hartvigsen et al., 2018), the most frequent causes of construction ill-health. Although there can be close links in time with apparent causal events, e.g. acute back pain associated with specific triggers such as awkward postures or handling heavy loads (Steffens et al., 2015), such ill-health more commonly arises due to cumulative and repeated exposures. Many workers underestimate the impact of such cumulative impacts (Revealing Reality, 2018).

Various interventions have been developed to address the impact of work-related ill-health in construction. In the United States, legislation on the highest risks such as asbestos, lead and silica has been in place for many years and has now been followed by practical guidance on health topics such as noise and chemical management (ASSP, 2017). Additionally, the 'fatal four' approach which targets the highest causes of fatalities (OSHA, 2017) has been extended to include a health based 'fatal four' (Gillen et al., 2019). In Australia, construction is one of the seven priority industries in its current Work Health and Safety Strategy, alongside a focus on six priority health conditions (Safe Work Australia, 2017). Mental health has been a key focus in recent years, with the development of the 'Mates' suicide prevention programme in Australia and subsequently in the UK (Mates, 2019; Mates in Mind, 2019). In the UK, the Health in Construction Leadership Group (HCLG) was established in 2014, bringing together key business leaders who recognise that, historically, the industry has 'shouted safety and whispered health' and that this needs to change if work-related ill-health in construction is to be reduced. In tandem with this, the UK Health and Safety 
Executive (HSE) has targeted construction health with various campaigns, and argues that the industry needs to manage 'health like safety' in order to move forward (HSE, 2019).

Within this context of high prevalence of work-related ill-health and complexity in causes and prevention, the aim of the research presented in this paper was to examine current approaches to managing health risks. Through semi-structured interviews $(n=237)$ and non-participant observations $(n=120)$ on two major construction projects in the UK, the research identified key factors contributing to the inadequate management of health risks. The research question 'what are the barriers to managing health as effectively as safety in construction?' was then addressed by reflecting on these factors and on how construction understands and manages safety risks.

\section{Method}

The data for this research were drawn from studies on two construction projects which had originally been conducted for a different purpose. Secondary analysis of selected data from the two studies was used to address the research question. The construction projects differed in size, scope and structure, providing access to a large and varied body of data, with opportunities to reflect on some of the similarities and differences between the projects and the effects of these. The research access differed slightly between the projects and this also added to the scope of the data set. Both studies were carried out in accordance with the [institution name removed to preserve anonymity] Ethical Framework .

\subsection{Regional Project}

The first project was a multi-million pound building project in the UK. The project owner and the lead contractor had committed to implementing good practices relating to occupational health services, management of health risks, and wellbeing. A large number of SMEs (Small and Medium Sized Enterprises) were engaged on the project, with a range of expertise in terms of managing health and safety risks.

The primary research on this project addressed the question 'How does good practice on major projects influence the health management practices of SMEs?' An experienced researcher, qualified in occupational health, recorded interviews with frontline workers (in small groups), SME supervisors, Occupational Safety and Health $(\mathrm{OSH})$ professionals and SME directors $(n=62)$. Additional data came from interviews with nine site managers and OSH professionals employed on behalf of the main contractor or the project owner (some were interviewed more than once). Further detail of the study design is available in [reference removed to preserve anonymity].

Analysis was conducted in NVivo 11 . The data were coded deductively using thematic analysis against a template developed to address the primary research question (King, 2004). Data coded under two themes, 'health risks' and 'health checks and medicals', and their associated sub themes, were extracted for inclusion in the current study.

\subsection{Megaproject}

The second project was a multi-billion pound infrastructure megaproject, involving several separate joint ventures (JVs). Substantial resources had been invested to ensure that the management of health and safety risks was of a high standard. Occupational hygiene provision and clinical $\mathrm{OH}$ services were procured by all the JVs through a mandated supplier.

The primary research question here was 'How does OSH strategy translate into practice on a megaproject?' Four experienced researchers were involved in data collection and analysis. A wide range of people across the project were interviewed over a three-year period $(n=160)$. Additional data were collected through attendance at project meetings and events $(n=120)$ over the same duration. In most cases, researchers 
attended these in a non-participant role, observing discussions and interactions and subsequently reviewing formal meeting notes where these were available. Meeting attendees were made aware of the researchers' role. Researchers also attended some events as participants, such as induction and other training sessions which were a requirement for individuals involved in the megaproject. Their reflections on these were included as part of the data set.

All data were analysed in NVivo using thematic analysis. A coding structure was developed collaboratively between the four researchers and included themes which had been pre-identified as important to the research questions, and further themes which emerged from the data (Braun and Clarke, 2006.) Samples of data were coded by all researchers, then reviewed to ensure themes were used consistently. Coding tasks were subsequently shared between researchers, with frequent discussion of emerging findings. Further information regarding the study design is available at [reference removed to preserve anonymity].

Data coded to 'health risk management,' 'occupational health,' fatigue', 'mental health' and 'design for health' (and their sub themes) were extracted for inclusion in the current study.

\subsection{Combined data}

Table 1 summarises the two construction projects where data were collected. It highlights the similarities and differences between the two projects and the differences in how the research was conducted on each.

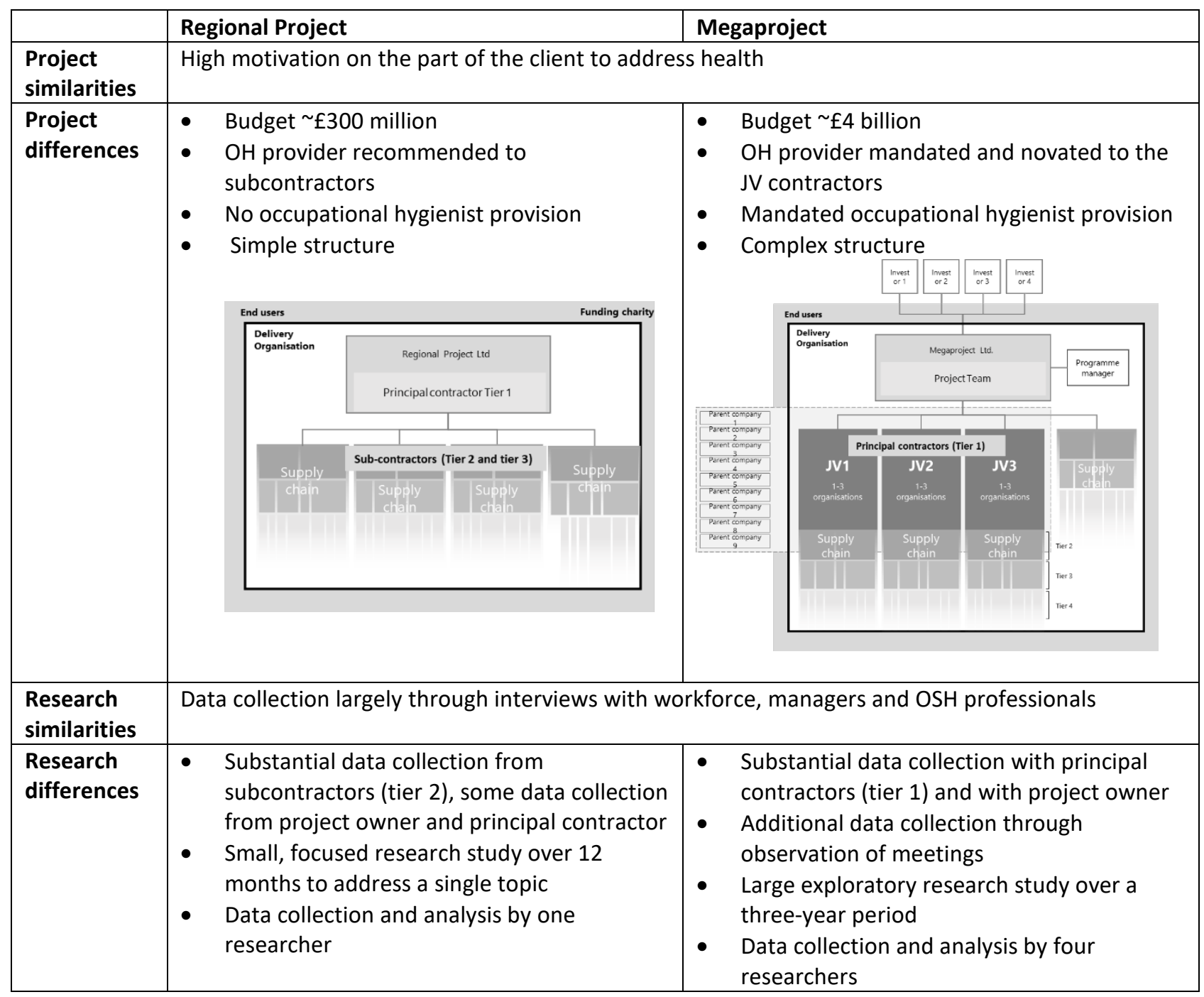


Figure 1 summarises the data from the two studies and shows how they were used together to address the current research question. Data extracted from the regional project were considered first, using thematic analysis in NVivo 11. Codes were chosen inductively to reflect the themes emerging from the data (Braun and Clarke, 2006) which related to the challenges of health risk management and how this differs from managing safety. The framework developed was then used to code data from the megaproject, adding extra codes where appropriate. Finally, the codes were revised and reorganised to identify the main themes and sub themes. The coding structure was then reviewed and validated by an independent researcher.

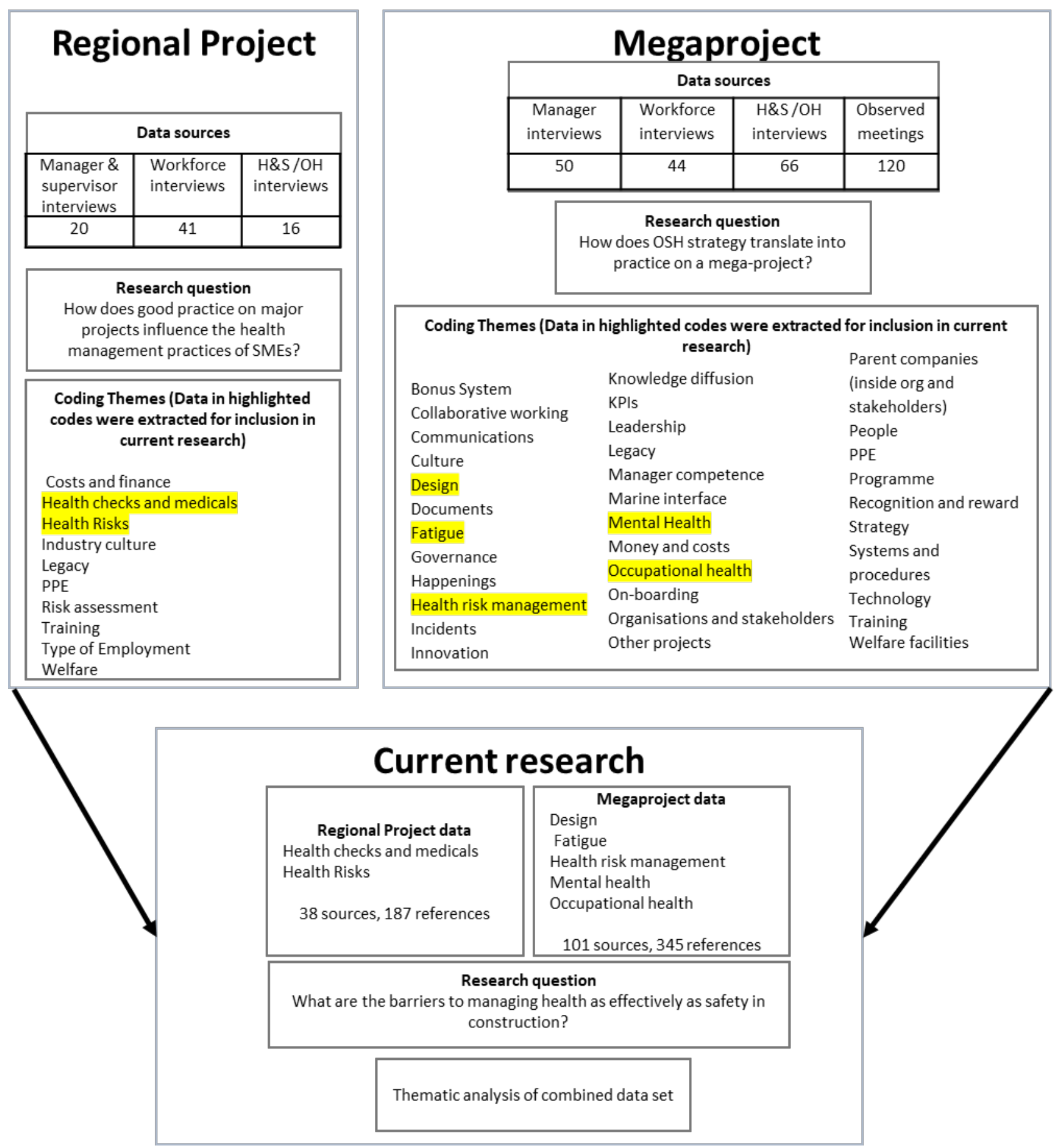




\section{Results}

Key factors were identified which contribute to the difficulties of managing health in construction. These include the commonly discussed intrinsic factors such as the long latency and invisibility of health conditions, which influence the way risk is perceived; but also broader aspects such as the way health is conceptualised and owned within the sector, the level of knowledge and expertise, and the structure of the sector itself.

For readers not familiar with UK construction, it is important to acknowledge the context, that the sector in general has a poor track record with regard to managing occupational health. The authors recognise the significant progress that has been made by a number of leading organisations, including those involved in this research. Whilst this study has identified areas for further improvement, and areas where there appears to be a lack of maturity in policies and protocols, the two projects are commended for what they have nevertheless achieved.

\subsection{Conceptualisation of the term 'health'}

On both projects the term 'health' was understood as a very broad concept and used in relation to a range of activities and circumstances. For example, in many of the interviews conducted, discussion about health was focussed (by interviewees) on non-work-related elements such as 'mini-medicals,' health promotion activities and wellbeing events: on the benefits of the employer influencing the workforce in their personal lives. This is different from the concept of work-related or occupational health, which refers specifically to the management of health risks which arise through work.

[The nurse] was very proactive in what she did, in actually getting people in for diabetes checks and blood pressure checks.

\section{SME Supervisor, Regional Project}

Personal health I think, which is a big, big issue and which when you look at most of our workforce they're migrant workers, you know, they live away from home, even if they had a GP [local doctor] at home they probably wouldn't see him..... they don't have personal healthcare or attention. And I think that's a big thing that we can change, we have, it's now common on sites to have your facility and your nurse, and everything else.

Senior manager, Megaproject

Evidence from both projects illustrates that many workers valued this provision of services to improve their health.

I didn't know you could be looked after like this. I was like, wow, I'm impressed. One of our mates, that was the day he realised that his sugar level was high. He said he had never been to a GP [family doctor] in all of his life.

Frontline worker, Regional Project

It seems like barely a day goes past where there's not an occupational health, 'oh by the way, if you're getting stressed, come in for this', or, just small things like that, but actually it all adds up to you thinking that actually there is support out there if you need it.

Engineer, Megaproject

Furthermore, the concept of health was not limited to physical aspects. On both projects there was a declared interest in mental health, with programmes to recruit and train mental health first aiders (MHFA). On the megaproject there was a substantial effort to increase worker awareness of mental health using the Mates in Mind 'start the conversation' model (Mates in Mind, 2019). This topic was discussed enthusiastically at health and safety meetings observed on the project, often much more so than other health topics. 
Health, as it was understood by participants in this study, therefore encompasses not just risks caused by work, or issues which might cause problems at work, but also aspects which relate to individuals' lifestyle choices: even where these might have no apparent impact on the workplace. In this respect it differs substantially from safety which focuses almost entirely on activities which occur within the confines of the construction project.

\subsection{Perception and tolerance of risk}

There were many examples on both projects of how workers perceived and tolerated health hazards in ways which increased their risk.

First, they sometimes perceived health risks as insubstantial because of their latency and prioritised the immediate situation over the long-term risks.

Interviewer: $\quad$ So, you do things that put your life at risk in the long-term?

Interviewee 1: $\quad$ The long-term, not immediately, yeah.

Interviewee 2: Yeah.

Interviewee 1: It might shorten it by a month or two, but then again, we all smoke and we all drink.

Frontline worker, Regional Project

This was particularly illustrated when there was perceived conflict between protecting health and protecting safety (e.g. because a mask to protect from dust made glasses steam up, or carrying dust extraction tools increased physical risk).

If I'm cutting MDF outside, I'll still put goggles on because MDF, when you're cutting it, it chips a bit, so obviously it goes into your eye. So, l'd rather put the goggles on than have the mask on.

Frontline worker, Regional Project

I mean it [powered dust extraction] does get more of the dust up, but it's just awkward to use.......you're better off with a mask and the bag on the saw yeah, definitely.

Frontline worker, Regional Project

This prioritisation of immediate risk over future risk was also seen at a more senior level. For example, on one section of the megaproject, the 'top 5 risks' for each work site were highlighted each month. Safety risks in these lists outnumbered health risks in the ratio of four to one. It is, however, difficult to compare hazards directly. Such decisions may reflect the latency and invisibility of health risks and how these impact on perception, but may be an accurate judgement of risk. This is illustrated by the consideration given to very high risk tasks, typically by designers and engineers on the megaproject. Often, the initial focus of risk discussions were 'the things that keep you awake at night', and these were all safety issues.

Understandably, health issues such as HAVS and NIHL were considered to be a lower priority than multiple fatalities or other catastrophic incidents.

If our cofferdam fails and we inundate the shaft and tunnels and the other shafts [with water], that's a lot, a lot of people [at risk of drowning].

Engineer, Megaproject

A second factor influencing risk perception was the invisibility of hazards themselves. Dust, noise and vibration are generally less evident than a worker at height or using heavy machinery, and they often need expert input to quantify them. Once this was done and highlighted on the current projects, the risk became more 'visible' and workers responded accordingly, such as those who managed their vibration exposure in response to monitoring wrist bands which warned them when they had reached a pre-defined limit. Where measurement was not in place, workers had to rely on their own expertise or personal judgement and might not assess risk accurately. 
Interviewer: And you mentioned noise, so your ear defenders, how do you know when it's noisy enough you need to put them on?

Interviewee: You can just tell, can't you?

Frontline worker, Regional Project

If signage is used to make health hazards more visible, it is important that it is accurate. For example, concerns were raised about noise signage being used to indicate 'mandatory protection zone'. It was sometimes in place with poor enforcement or used where noise was only sporadic, and thus undermined control measures. This inconsistency may reflect the difficulties of relying on signage on a construction site where the activities and hazards are often changing from day to day or even hour to hour.

A third factor influencing whether workers perceived health risk accurately was their level of knowledge. There were examples from both projects of workers who made poor judgments through lack of awareness, and of others who made good judgments because they understood the risk. Additionally, there were reports of worker behaviours that changed once they were helped to a better understanding of risk.

You learn from these big contracts ......so then you do realise when you go on another job, you're like, oh, well that was there for a reason, maybe I'll take it on to another job.

Frontline worker, Regional Project

It's like when you do go out on site and people aren't wearing hearing protection or masks, and when you actually educate them on why you need to wear them, that's when they conform.

OSH Professional, Megaproject

Finally, there were circumstances where workers recognised risk from health hazards but tolerated it because they believed it to be unavoidable or outside their control. This included the inevitably of MSDs for some roles, or exposures to dust and noise from other contractors' workers who created this (although some interviewees reported taking action, such as postponing work in those areas when they could).

Just generally peoples' knees get knackered if you've been working as a joiner for twenty years. So, there's nothing you can do, you can't escape that unfortunately; you've got to work on the floor.

Manager, Regional Project

I've been in scaffolding for twenty years now, as you know, you do feel it in your bones, yeah, you know because of the work that you do.

Frontline workers, Regional Project

Other interviewees had previously worked for companies with poor OSH controls, and tolerated high levels of risk because they felt their employment would be vulnerable if they challenged the status quo. This is likely to occur in relation to safety risks as well, but it will add to the impact from health risks which are already poorly managed. A contributory factor here is the high mobility and turnover of construction workers, which is a key feature of the way the industry operates, discussed further in section 3.5.

Most of the data on workers tolerating risk came from the regional project. This partly reflects the different sources of the data, but also indicates that health risks were more proactively managed on the megaproject. For example, acoustic barriers were frequently seen on the megaproject but were never seen or mentioned on the regional project. These are used to protect workers from noise generated elsewhere on a work site, and in their absence, workers have to rely on PPE (personal protective equipment) to protect themselves from such noise. Unfortunately, a tolerance of health risk appeared to be present not just individually but also at an organisational level. When discussing mental health on the megaproject, there was a widespread focus on the need to teach the workforce to be resilient and to help them discuss their concerns, as the industry is recognised as being high risk due to factors such as long hours, insecure 
employment and workers being away from their families. There was only a small amount of consideration given to whether the mental health risks could be addressed through better managerial practices, even though these were identified by some workers as a source of stress. There was even less attention to whether the current model of delivering construction projects could and should be challenged.

You have got transient workers, they possibly do not have long term job security, they are possibly in a huge percentage working away from their families and friends.... They may well have relationship difficulties and financial difficulties, all of these things just add up and I think your typical construction worker has so many of these elements that has the potential, the mental health will be a big thing for us as well.

OSH Professional, Megaproject

So, you have to consider all these factors when you're talking about fatigue management, maybe look at adjusting the hours or, you know, work something in to make it realistic... the site management are making no real changes to improve our physical state.

Frontline worker, Megaproject

In summary, therefore, health risks are often tolerated because the diseases they cause are relatively invisible and remote in time, and the hazards themselves have low visibility. Risk is sometimes judged incorrectly due to poor knowledge, and is tolerated by workers and organisations because of a perception of inevitability.

\subsection{Ownership of health}

There were challenges around the ownership of work-related health issues. This was typically perceived to be at the periphery of the responsibility of the role of the OSH professional and even further outside the role and expertise of managers and designers. Thus, addressing work-related health issues was viewed as something done by experts, i.e. by 'others'. This lack of ownership was epitomised on the megaproject by an $\mathrm{OH}$ standard which specified the details of how health and wellbeing would be managed. The section on 'responsibilities' focussed solely on the $\mathrm{OH}$ provider, with the $\mathrm{OSH}$ and project managers' involvement limited to managing the provider and ensuring they delivered against the standard.

Evidence of this difficulty came from both projects but there was wide variability between individuals, particularly in the level of knowledge that OSH practitioners had relating to health. Some were well informed and considered health to be as important a part of their role as safety.

I'm sure they think I just go on there for a gossip and a natter. But it's vitally important in what I do. When they're taking their gloves off, I can casually look at their hands to see if they're in typical builder shape or if, actually, they're okay.

OSH Professional, Regional Project

When I was with my previous contractor, I was teaching health risks in construction courses, you know, day long courses about noise, vibration, dust, what are the control measures, how we should be designing them out, all of those kinds of things.

OSH Professional, Megaproject

Others recognised that their level of knowledge was lower than that for safety and were keen to redress this.

That is my weakest part, health and wellbeing equally... what I'm impressed with [is the occupational hygienist on this project]... he's very articulate to anybody that'll listen, so I'm really excited about what I could learn from him. 
However, some felt it was more appropriate to hand over responsibility to the experts.

We have hygienists, actually physically out [there], specifically looking at the HAVS monitoring regime or the noise levels, or the noise protection zones, or the dust management... now if you were to lead on from that and say, well should the health and safety team be able to do that themselves, l'd say, yes in an ideal world, yes, but having seen how much the hygienists physically do within their own discipline, quite clearly you can't split yourself that many ways.

OSH Professional, Megaproject

Getting managers engaged in health at a strategic level was particularly challenging on both projects. Even for safety matters this was evident, with safety practitioners substantially outnumbering operational managers at health and safety meetings. For health matters, this was even more marked. Work on mental health, for example, was led by safety teams and by health practitioners. These individuals recognised that intervention to reduce risk (e.g. to change manager behaviour) would need to be led by senior managers, but there was no evidence of an organisational appetite to do this.

The view that health is an expert role was reinforced by the way management data and metrics were used, particularly on the megaproject. For example, at one regular team meeting a slide was included which showed what the occupational health practitioner had done that month - the number of people seen, the details of training sessions provided. There was, however, little discussion about the relevance of this to the $\mathrm{OSH}$ function or to managers. Similarly, a slide presented to senior executives monthly included only an overall score of how well health was being managed. Accident statistics were presented on the slide, including a breakdown of the location of injuries, allowing managers to engage easily in discussions about the causes and possible solutions to these. However, equivalent data showing the most frequent exposures to health risks (such as from noise or manual handling) were not included, even though they had been collected, and were being used by health practitioners to develop their practice.

Encouragingly there was evidence from both projects that those with health expertise were working hard to share their knowledge and to encourage OSH practitioners and managers to take more ownership for health. On the regional project, for example, there was support for supervisors to undertake risk assessments for workers with health issues. On the megaproject, there was training for designers to encourage them to address health issues at source, targeted training to managers and engineers who needed to carry out risk assessment for work-related health risks, and the production of written 'standards' to highlight the key features of such risk assessments.

It was the monthly health and safety meeting that she [the $\mathrm{OH}$ nurse] sat in on, and yeah, there was a section on the agenda for health and health surveillance. She was imparting her knowledge during that period... she was pushing us, which was good.

Manager, Regional Project

[On a previous project] what we actually got the engineers and shift managers to do, was actually [to] train up on how to use real time dust monitoring equipment... [they] started to take ownership of their own sort of dust problems rather than saying, 'it's a hygienist, it's their issue to deal with'. It was much more, 'it's our issue with the hygienist's support'.

OSH Professional, Megaproject

There was, therefore, evidence of progress regarding the extent to which health was managed alongside safety; butstill a long way to go to achieve parity between health and safety both for OSH professionals and for managers.

\subsection{Lack of clarity over health requirements}

On both projects there was an element of confusion or uncertainty around the exact requirements for health, particularly in terms of health assessment. This resulted in some inconsistency in how arrangements 
were made on the regional project, some companies decided not to do health checks because they felt it was too problematic.

Most difficulties in this area related to poor or incomplete knowledge, often on the part of OSH practitioners. For example, some SMEs on the regional project were keen to gather detailed health information about their workforce, even though they had no-one with the expertise to interpret the information. At the same time, they had inadequate processes in place for health surveillance. There was often poor understanding of the difference between health surveillance (legally mandated), fitness for work health assessments (occasionally legally mandated, but mostly good practice) and health checks for wellbeing purposes (voluntary) (CONIAC, 2015).

There was also some uncertainty, particularly amongst SMEs on the regional project, about the required frequency of different elements of health surveillance. The $\mathrm{OH}$ provider on the regional project had asked that a number of workers be referred back for follow up for various reasons (e.g. to arrange for additional surveillance for HAVS, or to do review testing of hearing or lung function). Over an 18-month period, none of these requests were acted on by employers, further suggesting limited understanding by employers and workers of the importance of ongoing and accurate surveillance.

It's just becoming unmanageable really, I thought I had got to the position with them where we had agreed three years unless somebody had an issue and it needed to be followed up more frequently. But I think they have just been reverting to the HSE guidance for these different frequencies, not realising really it's impossible to deliver.

\section{OSH Professional, Regional Project}

Even when there was agreement and understanding that health assessment was required, there was still uncertainty and debate around the details. For example, some argued that health surveillance should be risk based, depending on individual exposures. Others favoured a blanket approach given the uncertainties over what roles a worker might take on different sites. The fact that workers are often exposed to noise and dust produced by others, regardless of their own role, was also an argument for this approach. Similarly, there were many discussions on the megaproject around safety critical medicals - what these should include, what standards should be set and how frequently they should be done (e.g. should they be done more frequently as workers get older or was that discriminatory?)

\subsection{Industry structure}

On both projects, there was evidence that some aspects of health management were particularly challenging to manage due to the way the construction industry operates. This includes its project-based nature, the formation of temporary structures and organisations (e.g. Joint Ventures), the engagement of multiple tiers of contractors, and the fact that many workers are self-employed or work through agencies.

First, there was a challenge around the practicalities of arranging health assessments and any necessary follow-up, particularly who should pay for them (the direct costs and also the costs of worker downtime, which can be significant for sole traders and small companies), and to whom reports on fitness for work should be circulated. The logistics of workers based on sites remote from both $\mathrm{OH}$ service providers and family doctors (who may be involved in follow up) was also problematic. This evidence came from the regional project, as it is an issue which is of particular interest to SMEs, working at tier 2 and below.

Something we have had to work on hard on, really... everybody has got a different opinion as to what's the, you know, medical information versus fitness information and who that can even be conveyed to in the company. 
Our biggest problem is logistics, getting them [the workforce] to the person that undertakes it [i.e. the $\mathrm{OH}$ provider], so in this regard having a facility on site made it slightly easier.

Manager, Regional Project

Secondly, the shape of the industry makes a holistic perspective on worker data very difficult: for it to follow them from one project to another so that there would be a complete record, and patterns could be seen. Health surveillance requires consideration of change over time not just a one-off assessment. $\mathrm{OH}$ providers on both projects did not try to obtain worker health records from previous providers. This was partly because of data consent issues but also because to do so would be difficult and of limited benefit given that workers would move on again soon anyway.

All the guys that are working on this project with us will [move on], chances are the next project will be different guys because the job will be in a different area... we don't bring these lads from site to site because this is that far away from where we normally work... we use local labour.

Manager, Regional Project

Thirdly, variability and lack of consistency across the wider construction industry was a barrier to good implementation of health arrangements. Interviewees on both projects commented that small companies that did these consistently would price themselves out of work when competing with less principled employers. Therefore, such practices will not become embedded if they are demanded only by a small number of large clients.

If the client doesn't specify and doesn't require a certain level, don't be surprised that the level that you get will be the cheapest they can possibly get away [with]... It's still a race to the bottom within our industry and they will do the very bare minimum to satisfy the contract.

OSH Professional, Megaproject

They are taking a lot of convincing as to the value of what we want them to do. And in many cases, the value is it's just the moral way of doing it or the better way of doing it but it doesn't necessarily bring you returns in terms of financial - just the health of your workforce - but it is hard to demonstrate that to commercial people.

OSH Professional, Megaproject

Finally, interviews on the regional project highlighted the perception that workplace management of health can have negative impacts on workers themselves as fitness for work assessment and health surveillance might have adverse outcomes. Workers who are absent rarely get sick pay, and workers were vocal about the employment risks of declaring health issues to some companies they had worked for.

If they see it as a sign of weakness, "Oh this guy's going to be, he's hurt his back and he can't do this, he can't do that, well we'll replace him."

Frontline worker, Regional Project

[What do you do, as a scaffolder if you get a bad back?] Think about painkillers and shut up and try and carry on. Until it gets to the point basically where you can't, and then you go and see a doctor then. But you try... you've got to survive and if you don't work, you're not getting paid.

Frontline worker, Regional Project

The $\mathrm{OH}$ providers confirmed that this was a valid concern. It made some workers reluctant to engage in health assessment where it was offered, and also led to some workers with health conditions choosing to work for employers who did not carry out assessments.

[One worker] was insulted, he was offended that we insisted he had a medical, he thought it was because of his age, because he smokes, he was kind of a little bit sinister about it and insisted he will 
not use our occupational health nurse. If we want him doing, he will go to his own GP and we will be paying for it.

Manager, Regional Project

Despite the challenges, there was evidence that a number of employers were trying to improve their performance in this area. On the regional project, there was a motivation to support the supply chain in embedding their own arrangements. This is a change from previous major projects where the lead contractor provided facilities centrally, ensuring provision for all but also making it very difficult for joined up worker records to be created.

[On the Olympics] it was more about doing everybody's medicals as they came through the door, everybody's health surveillance and spoon-feeding the supply chain a lot to make sure everybody had what they needed. Whereas now the big drive... is to get the supply chain to engage with an occupational health provider and look after their own workforce.

OSH Professional, Megaproject

Several of the SMEs on the regional project had already taken steps to procure $\mathrm{OH}$ services to some extent and were keen to develop this further.

So, we always had an ambition to carry out health surveillance, it kind of fell by the wayside a little bit and this job helps us push that, it prompted our thoughts a little bit more.

Manager, Regional Project

Overall, the industry operates in a way which mitigates against comprehensive health assessment and management of health records. There is, however, evidence of motivation in some areas to address this if some of the logistical challenges can be overcome.

\section{Discussion}

This research used data from two construction projects in the UK to examine why a high prevalence of work-related ill-health persists in the industry and to identify the barriers to managing health risks effectively. Common explanations given in the literature often focus on the latency and low visibility of health conditions. These factors are certainly important, and their impact was seen in this research. Workers generally recognised that health hazards such as noise, dust and vibration were present in their work and that they might lead to ill-health. However, some failed to understand the level of risk, as they either underestimated their exposure or overestimated the effectiveness of PPE. The apparent lack of consequence from this enabled them to maintain their belief that they were adequately protected. There was also, amongst some, a fatalistic attitude towards the consequences of these risks, which is a phenomenon reported elsewhere (Holmes et al., 1999, Boatman et al., 2015). Again, the long-term nature of the illnesses may contribute to this if workers conflate work-related ill-health with the 'normal' deterioration they expect with ageing anyway, distinct from the 'abnormal' deterioration that might be apparent following a workplace accident.

However, this research found that many of the barriers to better management of health risks were not about the hazards themselves but rather, about the way they were addressed. This included factors such as incomplete knowledge, lack of ownership or responsibility for health by some managers and OSH professionals, and the way in which health as a concept was defined and understood.

Figure 2 summarises the findings of this investigation, indicating how the different factors appear to interact to underminemanagement of health hazards and risks. The figure also proposes underlying causes of this situation. A contemporary approach to improving health management in the UK has been a recommendation that employers should treat health like safety (HSE, 2019; Tyers and Hicks, 2012). In fact, 
the underlying challenges appear to arise because health is not like safety. There are differences in terms of the hazards themselves but also in the way in which the industry understands and manages risk. It is argued that it is these factors which the industry needs to address if it is to improve occupational health management. The following section contrasts health with safety, highlighting their different challenges and how this influences the management of health risks.

\subsection{What is 'workplace health' ?}

It was apparent from the interviews and meeting observations undertaken for this research that health was understood in very broad terms and included the personal, physical and mental health of the workforce beyond the workplace. This aligns with the definition of occupational health by the ILO and the WHO (WHO, 1994) as including the "enhancement of physical, mental and social well-being of workers". By comparison, safety is typically much more tightly defined within policy documents, on company websites and in training summaries, as focussing very specifically on 'the workplace'(e.g. NEBOSH, 2019).

This focus on the personal health of the workforce and an enthusiasm to improve it has been an evolving feature of major construction projects in recent years in the UK. For example, the vision during construction of the Olympic Park for London 2012 included 'enhancing the wellbeing of all involved in the project work' (Waterman, 2007). Health promotion activities were also in evidence during construction of Heathrow Terminal Five where lifestyle medicals were offered 'to encourage people to think seriously about health issues, both within and outside the work environment' (Evans, 2008). Similar initiatives have occurred on construction projects in Australia, Ireland and the Netherlands (Thabit et al., 2013, Lingard and Turner, 2015, Viester et al., 2018). 


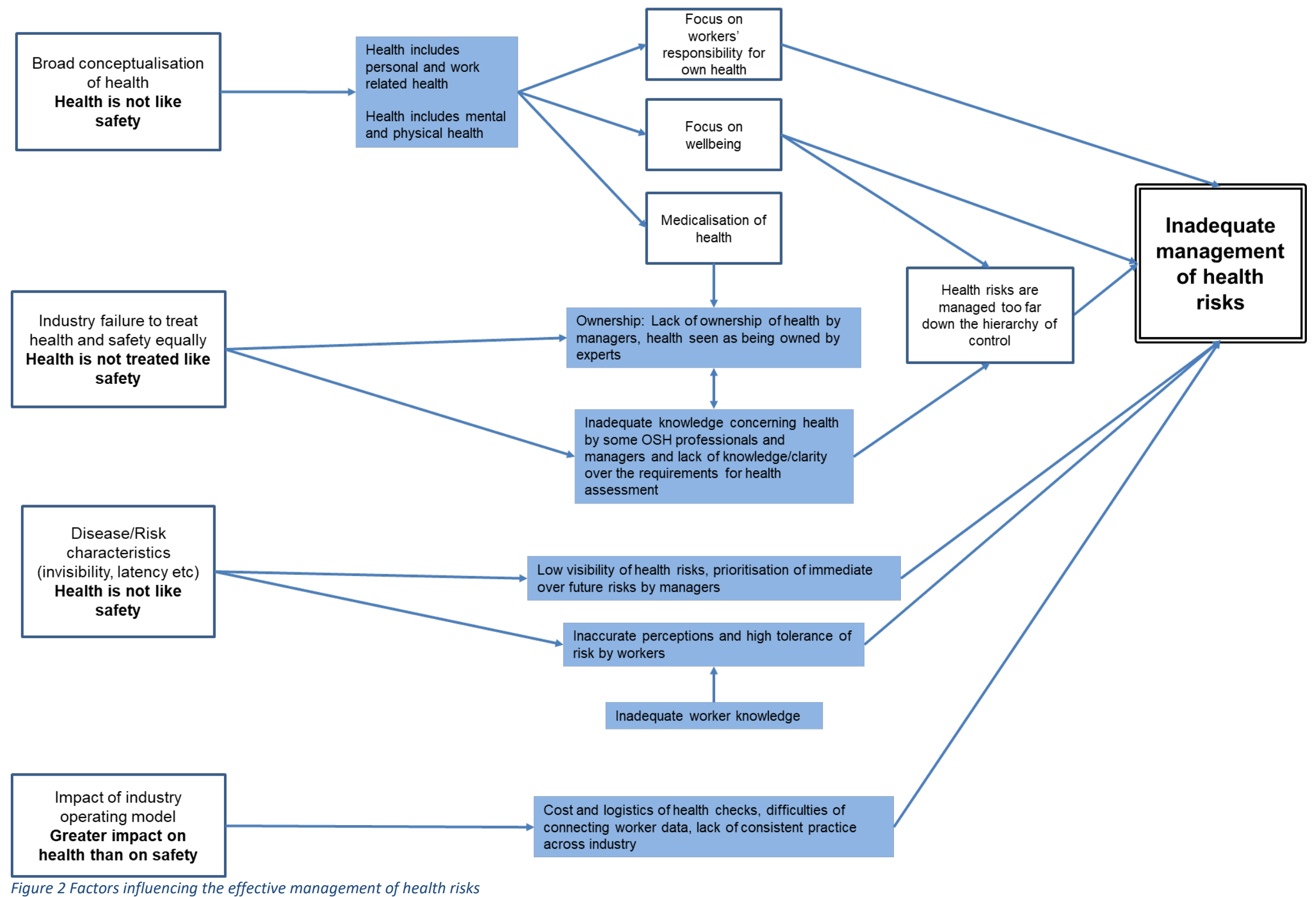

Figure 2 Factors influencing the effective management of health risks 
Arguments in favour of such interventions are both moral and practical. This includes addressing the high incidence of cardiovascular disease and diabetes amongst construction workers (Arndt et al., 2005, Thabit et al., 2013, Järvholm et al., 2014) and the impact such poor health can have on productivity, safety and work attendance. These challenges have been brought into particular focus as pension ages rise in many developed countries (Chomik and Whitehouse, 2010), requiring the workforce to be work fit to age 67 and beyond (Eaves, Gyi and Gibb, 2016, Drake, Haslam and Haslam, 2017). UK governments have strongly encouraged employers to get involved in wellbeing initiatives and to promote the workplace as a setting for interventions to improve overall health (Black, 2008, 2016) and similar expectations and initiatives can be found elsewhere in Europe (Buffet et al., 2013, ENWHP, 2018).

However, there was some evidence in this research that focussing on health in this way can lead to distraction from managing work-related health risks. The potential for 'wellbeing' activities to divert energy and resources from the priority of reducing exposure to workplace risks has been identified by others such as Sherratt (2018) and Waterman (2018). Additionally, there is a risk that employers develop a false sense of security because they are at least doing 'something' about health, and that workers get unclear messages about what the priorities are in terms of health management. This concern was illustrated by the former chairman of Crossrail who commented that, '...it's no good giving people fruit and porridge as they come through the turnstile if we're then giving them exposure to dust and carcinogens...' (CIOB, 2016).

The wellbeing model tends to focus on the responsibilities of workers to change their behaviours, potentially encouraging employers to retreat from some of their own responsibility for managing risk (Sherratt, 2015). An example of this is the well-intentioned focus on mental health in construction, which encourages workers to identify and seek help for their problems but does not commit organisations or the industry to taking action to reduce the risks inherent in the sector. Similarly, there is evidence, particularly from Australia, that the failure of workers to engage in healthy exercise or dietary behaviours is often influenced by practical and organisational factors such as long working hours or commute times (Lingard and Turner, 2015, Langdon and Sawang, 2018), too-short breaks (Townsend, Loudoun and Markwell, 2016) or physical fatigue (Lingard and Turner, 2017).

\subsection{Disparity in focus on safety over health}

This research found that some managers and OSH professionals lacked adequate knowledge about health and also did not always take ownership of health risks as they would for safety. This may relate to a perception that health is a personal, and sensitive topic (particularly given the inclusion of personal health and wellbeing in the concept of health). However, it is also likely to be influenced by the wider inequity between health and safety within construction. In the UK, 'health and safety' training provided by recognised bodies (such as that offered by NEBOSH, IOSH etc), generally has much less time and attention allocated to health than to safety risk management in course outlines. This imbalance then persists when $\mathrm{OSH}$ is discussed at a senior level in companies, as in this research where health management data were not commonly included alongside safety management data at executive meetings. This disparity relates predominantly to those health hazards which have consequences in the future. Where there is immediate harm, such as chemical burns or acute onset MSDs, these are likely to be reported within 'accident' statistics. Longer term health conditions are more rarely reported, and may not reflect current exposures, so that reporting of health risk management would be more relevant; but is difficult, even if managers and organisations have good knowledge and high motivation. The overall consequence of this inequity is that workers may absorb a message that workplace health is a low priority or that the risks are low.

This is not an issue limited to the UK. For example, in the United States, industry guidance from the American Society of Safety Professionals (ASSP) takes the form of 42 guidance documents on various aspects of health and safety. Of these, only four are specific to health risks and these have been added relatively recently. In New Zealand, a strategy document published in 2016 acknowledges the need for intervention as "the health and safety system has so far failed to adequately address work-related health risks and the harm associated with them" (WorkSafe New Zealand, 2016). 
The academic literature on $\mathrm{OSH}$ is similarly skewed. A preliminary search for papers about modelling or quantifying $\mathrm{OSH}$ risk management found that many authors mentioned health risks in their introduction but then focussed exclusively on safety hazards (e.g. Sousa et al., 2015). Others referred to 'injuries and illness' but include only acute injuries from manual handling in their concept of illness (Fredericks et al., 2005, Pinto, Nunes and Ribeiro, 2011).

This bias persists in current models of OSH management. For example, the vision of 'zero', i.e. no harm to the workforce at work is very much rooted in safety. Although it can be used as a philosophical approach to drive improvements in safety, health and wellbeing (e.g. Zwetsloot, Leka and Kines, 2017) organisations commonly focus on metrics such as accident frequency rates and fatalities as a way of illustrating their progress in this area (Panopoulos and Booth, 2007, Wang and Griffis, 2018). The 'Safety Differently' philosophy (Dekker, 2014) also struggles to recognise health hazards as significant, with a focus on lifethreatening incidents, viewing the causes of these as different from the causes of minor accidents. As most occupational health conditions such as HAVS, NIHL and MSDs are disabling, distressing and possibly life changing, but not generally life ending, they could therefore be missed by this conception.

Incomplete worker knowledge was a finding of this research, as it has been elsewhere (Tam and Fung, 2008, Lingard and Turner, 2015). This is not unique to health, it is a challenge in safety management also (Wilkins, 2011, Bluff, 2019). However, given the particular challenges of managing health risks, relatively greater knowledge is probably needed to positively influence behaviour. There is a benefit therefore in addressing, health risks in ways that do not rely on worker knowledge and good practice. The hierarchy of control model advocates that risks should be designed out at source wherever possible or be managed through engineering controls such as better tool design or extraction systems. Only where these are insufficient solutions should there be reliance on management and administrative systems or on the use of PPE as a last resort. This model requires expertise amongst managers, designers and OSH professionals to recognise that problems exist as well as the competence to implement appropriate solutions (Kramer et al., 2010, Geier et al., 2011). Encouragingly this research found evidence of progress in this area. The megaproject, in particular, had programmes to train and coach managers and designers and to ensure that health risk was considered at an early stage of design. They were in this respect, and in their management of health risk more generally, further developed than the regional project. Both projects had recognised the need for good practice and were progressing towards it, but the megaproject had more mature arrangements. This highlights the benefits of embedding health in projects at an early stage and ensuring that there is adequate expertise to support good practices. However, the improved standards on the megaproject were also undoubtedly enabled by the greater funding available on this major development.

\subsection{Impact of industry operating model}

This research has illustrated the important role that major projects have to play in improving standards in construction more widely. On both projects, there was evidence of small companies adopting new habits as a result of external expectations. This illustrates the importance of 'trickle down' (Finneran and Gibb, 2013, Pinder et al., 2016), whereby good practices start on major projects, and are then adopted more widely. This increases the likelihood that they will eventually be accepted as standard practice across the sector and is an important mechanism for the improved management of health risks.

This process is particularly important given the structure of the construction sector, both in the UK and elsewhere. This research confirmed that this brings additional challenges to the management of health hazards. The fragmented nature of construction and the relatively high proportion of the workforce who are self-employed or working through agencies is not a new issue (e.g. Gibson, 2002), and presents a challenge for safety as well as for health. However, it arguably has a greater impact on health due to the personal nature of health risk. For example, health assessments and health surveillance can be an important part of health management and often a legal requirement. These incur costs but there are few obvious benefits to the employers that pay for these, due to the itinerant nature the workforce. The high 
turnover of workers and their movement between projects can also make it very difficult to link their health records over their working lives.

In the UK, a solution was developed to address this problem with the establishment of Constructing Better Health in 2004, which provided guidance to small companies, promoted health assessments and developed a central worker health database (HSE, 2005, Tyers et al., 2007). However, the Constructing Better Health initiative has faced ongoing challenges (B\&CE, 2016) and a replacement occupational health management system is currently in development (B\&CE, 2017). Regardless of how effective this process is, there are substantial obstacles to overcome. Only $18 \%$ of the total UK workforce has access to occupational health services (EC, 2017) and coverage within construction is likely to be even lower than this, as OH service provision is generally worse for self-employed workers or those within SMEs (Colosio et al., 2017). This is a problem in many countries and many industries. Three quarters of the world's workers and over half of Europe's workers have no access to OH services (Rantanen, Lehtinen and lavicoli, 2013, Rantanen et al., 2017). Only in countries which have compulsory provision of funded $\mathrm{OH}$ services such as France (Girogio, 2019) and Finland is better coverage achieved.

\subsection{Study strengths and limitations}

This research used secondary data from research on two different construction projects. This is both a limitation and a strength. The researchers' access differed between the two projects. This influenced the data collected and potentially limits the scope to draw comparisons. For example, on the megaproject, researchers had less access to the SMEs, particularly to their front-line supervisors, than on the regional project. However, the megaproject provided much greater access to attend meetings and observe decision making in progress. Overall, the combination of the two sets provided access to a wide range of individuals and to varied and comprehensive data from other sources. Additionally, because of the itinerant nature of construction, many of those interviewed had previously worked on a variety of projects including very small ones and participants shared their experiences of this. Consequently, the findings of this study illustrate many broader issues in the sector beyond the two specific projects studied.

A second potential limitation is that the data used to answer the current research question were originally collected to address two different research questions. However, the topics explored on both projects were very similar. Interviews and meeting observation notes on both studies were wide ranging and relatively unstructured, covering many views on health at work. This is potentially an advantage over more structured questions which might have narrowed down responses.

\subsection{Concluding remarks}

Construction workers worldwide are at high risk from work-related ill-health and this problem persists even in countries which have made good progress in reducing safety risks. This research illustrates the different challenges in managing work-related health hazards, risks and exposures compared with those affecting safety. Health differs not only in the nature of the hazards and risks but also, importantly, in the way health is perceived and managed. Therefore, the industry needs to consider targeted intervention if it wishes to see improvement in the ways health risks are addressed.

To achieve this, future work could focus on:

- Improving the knowledge of managers, OSH professionals and frontline workers to compensate for the perceived remoteness and intangibility of health risks and their consequences

- Identifying clearly who 'owns' health within construction

- Improving hierarchy of control for health risks so that elimination of risks and engineering solutions take precedence over PPE

- Continuing efforts to improve access to $\mathrm{OH}$ services and improving the management of health data across the sector. 
Further details of how these developments might work in practice are included in a companion paper (reference withheld to preserve anonymity) which includes specific examples of good practice identified during this research.

Underpinning this is a need for the industry to agree how it defines 'health' when it talks about health and safety. Progress is unlikely unless there is a real commitment throughout the sector to give health parity with safety. There is also a need for rigorous research studies, examining the efficacy of health intervention approaches in construction, providing a more solid foundation for evidence-based practice.

Acknowledgments

[removed to preserve anonymity]

\section{References}

ARNDT, V., ROTHENBACHER, D., DANIEL, U., ZSCHENDERLEIN, B., SCHUBERTH, S., and BRENNER, H., 2005. Construction work and risk of occupational disability: a ten year follow up of 14474 male workers. Occup Environ Med [online]. 62, pp. 559-566. Available from: http://oem.bmj.com/ [Accessed 8 Jan 2019].

ASSP, 2017. Construction and Demolition Operations (A10) [online]. [online]. Available from: https://www.assp.org/standards/standards-topics/construction-and-demolition-operations-a10 [Accessed 11 Mar 2019].

B\&CE, 2016. Occupational health in construction Research Findings [online]. [online]. Available from: http://bandce.co.uk/wp-content/uploads/2016/12/BCE-occupational-health-in-construction_research-findings.pdf [Accessed 15 Jan 2019].

B\&CE, 2017. Occupational health in construction [online]. [online]. Available from: https://2ihxox21inu92ajbbx2yez7v-wpengine.netdna-ssl.com/peopleshealth/wpcontent/uploads/sites/3/2018/12/BCE-occupational-health-in-construction-research-findings.pdf [Accessed 11 Feb 2019].

BISWAS, G., BHATTACHARYA, A., and BHATTACHARYA, R., 2017. Occupational health status of construction workers: A review. International Journal of Medical Science and Public Health [online]. 6 (4), p. 1. Available from: http://www.ijmsph.com [Accessed 8 Jan 2019].

BLACK, C., 2008. Working for a healthier tomorrow. TSO.

BLACK, D.C., 2016. An Independent Review into the impact on employment outcomes of drug or alcohol addiction, and obesity [online]. DWP. Available from: https://www.gov.uk/government/publications/ [Accessed 21 Jan 2019].

BLUFF, E., 2019. How SMEs respond to legal requirements to provide information, training, instruction and supervision to workers about work health and safety matters. Safety Science [online]. 116, pp. 45-57. Available from: https://www.sciencedirect.com/science/article/pii/S0925753518306659 [Accessed 11 Mar 2019].

BOATMAN, L., CHAPLAN, D., TERAN, S., and WELCH, L.S., 2015. Creating a climate for ergonomic changes in the construction industry. American Journal of Industrial Medicine [online]. 58 (8), pp. 858-869. Available from: http://doi.wiley.com/10.1002/ajim.22499 [Accessed 21 Jan 2019].

BORUP, H., KIRKESKOV, L., HANSKOV, D.J.A., and BRAUER, C., 2017. Systematic review: chronic obstructive pulmonary disease and construction workers. Occupational Medicine [online]. 67 (3), pp. 199-204. Available from: https://academic.oup.com/occmed/article/67/3/199/2997467 [Accessed 8 Jan 2019]. 
BOSCHMAN, J.S., VAN DER MOLEN, H.F., SLUITER, J.K., and FRINGS-DRESEN, M.H.W., 2011. Occupational demands and health effects for bricklayers and construction supervisors: A systematic review.

American Journal of Industrial Medicine [online]. 54 (1), pp. 55-77. Available from:

http://doi.wiley.com/10.1002/ajim.20899 [Accessed 11 Jan 2019].

BRAUN, V. and CLARKE, V., 2006. Using thematic analysis in psychology. Qualitative Research in Psychology [online]. 3 (2), pp. 77-101. Available from:

http://www.tandfonline.com/doi/abs/10.1191/1478088706qp063oa.

BUDD, D., HOLNESS, D.L., and HOUSE, R., 2018. Functional limitations in workers with hand-arm vibration syndrome (HAVS). Occupational Medicine [online]. 68, pp. 478-481. Available from:

https://academic.oup.com/occmed/article-abstract/68/7/478/5043262 [Accessed 11 Jan 2019].

BUFFET, M.-A., L. GERVAIS, R., LIDDLE, M., and EECKELAERT, L., 2013. WELLBEING AT WORK : CREATING A POSITIVE WORK ENVIRONMENT [online]. Luxembourg. Available from:

https://osha.europa.eu/en/publications/literature_reviews/well-being-at-work-creating-a-positivework-environment/view [Accessed 10 Jan 2019].

CHOMIK, R. and WHITEHOUSE, E., 2010. Trends in Pension Eligibility Ages and Life Expectancy, 1950-2050 OECD Social, Employment and Migration Working Papers, No. 105 [online]. Paris. Available from: https://doi.org/10.1787/5km68fzhs2q4-en. [Accessed 20 Feb 2019].

CIOB, 2016. Health summit: industry leaders outline the challenge | Construction Manager - News.

Construction Manager [online]. Available from:

http://www.constructionmanagermagazine.com/news/health-su4mmit-in3dustry-lea4ders-challenge/ [Accessed 18 Mar 2019].

COLOSIO, C., VAN DIJK, F., MANDIC-RAJCEVIC, S., GODDERIS, L., HULSHOF, C., and VAN DER LAAN, G., 2017. Workers' health surveillance: implementation of the Directive 89/391/EEC in Europe. Occupational Medicine [online]. 67 (7), pp. 574-578. Available from:

http://academic.oup.com/occmed/article/67/7/574/4085584/Workers-health-surveillanceimplementation-of-the [Accessed 13 Mar 2019].

CONIAC, 2015. Occupational health risk management in construction [online]. Available from: http://www.hse.gov.uk/aboutus/meetings/iacs/coniac/coniac-oh-guidance.pdf [Accessed 21 Jan 2019].

DEKKER, S., 2014. Safety Differently [online]. Boca Raton: CRC Press. Available from: https://www.taylorfrancis.com/books/9781482242003 [Accessed 21 Jan 2019].

DIEPGEN, T.L., 2003. Occupational skin-disease data in Europe. International Archives of Occupational and Environmental Health [online]. 76 (5), pp. 331-338. Available from: http://link.springer.com/10.1007/s00420-002-0418-1 [Accessed 11 Jan 2019].

DRAKE, C., HASLAM, R., and HASLAM, C., 2017. Facilitators and barriers to the protection and promotion of the health and safety of older workers. Policy and Practice in Health and Safety [online]. 15 (1), pp. 418. Available from: http://www.tandfonline.com/action/journallnformation?journalCode=tphs 20 [Accessed 22 Nov 2018].

EAVES, S., GYI, D.E., and GIBB, A.G.F., 2016. Building healthy construction workers: Their views on health, wellbeing and better workplace design. Applied Ergonomics [online]. 54, pp. 10-18. Available from: https://www.sciencedirect.com/science/article/pii/S0003687015301058 [Accessed 22 Nov 2018].

EC, 2017. COMMISSION STAFF WORKING DOCUMENT Ex-post evaluation of the European Union occupatinal safety and health Directives (REFIT evaluation) [online]. Brussels. Available from: https://eur- 
lex.europa.eu/legal-content/EN/TXT/PDF/?uri=CELEX:52017SC0010\&from=en [Accessed 16 Apr 2019].

ENWHP, 2018. Luxembourg Declaration on Workplace Health Promotion in the European Union 2 Luxembourg Declaration on Workplace Health Promotion [online]. Available from:

https://www.enwhp.org/resources/toolip/doc/2018/05/04/luxembourg_declaration.pdf [Accessed 18 Mar 2019].

EVANS, M., 2008. Heathrow Terminal 5: health and safety leadership. Proceedings of the Institution of Civil Engineers - Civil Engineering [online]. 161 (5), pp. 16-20. Available from: http://www.icevirtuallibrary.com/doi/10.1680/cien.2007.161.5.16 [Accessed 7 Jan 2019].

FALKINER, S., 2003. Diagnosis and treatment of hand-arm vibration syndrome n. Aust Fam Physician [online]. 32, pp. 530-34. Available from: https://www.racgp.org.au/afpbackissues/2003/200307/20030705falkiner.pdf [Accessed 8 Jan 2019].

FINNERAN, A. and GIBB, A., 2013. Safety and Health in Construction Research Roadmap-Report for Consultation [online]. ClB-W099. Available from: http://site.cibworld.nl/dl/publications/pub_376.pdf [Accessed 21 Jan 2019].

FRANSSEN, F.M.E., SMID, D.E., DEEG, D.J.H., HUISMAN, M., POPPELAARS, J., WOUTERS, E.F.M., and SPRUIT, M.A., 2018. ARTICLE The physical, mental, and social impact of COPD in a population-based sample: results from the Longitudinal Aging Study Amsterdam. Primary Care Respiratory Medicine [online]. 28, p. 30. Available from: www.nature.com/npjpcrm [Accessed 14 Nov 2018].

FREDERICKS, T.K., ABUDAYYEH, O., CHOI, S.D., WIERSMA, M., and CHARLES, M., 2005. Occupational Injuries and Fatalities in the Roofing Contracting Industry. Journal of Construction Engineering and Management [online]. 131 (11), pp. 1233-1240. Available from: https://ascelibrary.org/doi/pdf/10.1061/\%28ASCE\%2907339364\%282005\%29131\%3A11\%281233\%29 [Accessed 11 Jan 2019].

FROST, G., 2013. The latency period of mesothelioma among a cohort of British asbestos workers (19782005). British Journal of Cancer [online]. 109 (7), pp. 1965-1973. Available from: http://www.nature.com/articles/bjc2013514 [Accessed 10 Oct 2018].

FROUD, R., PATTERSON, S., ELDRIDGE, S., SEALE, C., PINCUS, T., RAJENDRAN, D., FOSSUM, C., and UNDERWOOD, M., 2014. A systematic review and meta-synthesis of the impact of low back pain on people's lives. BMC Musculoskeletal Disorders [online]. 15 (1), p. 50. Available from: http://bmcmusculoskeletdisord.biomedcentral.com/articles/10.1186/1471-2474-15-50 [Accessed 14 Nov 2018].

GEIER, J., KRAUTHEIM, A., UTER, W., LESSMANN, H., and SCHNUCH, A., 2011. Occupational contact allergy in the building trade in Germany: influence of preventive measures and changing exposure. International Archives of Occupational and Environmental Health [online]. 84 (4), pp. 403-411. Available from: http://link.springer.com/10.1007/s00420-010-0581-8 [Accessed 11 Jan 2019].

GIBB, A., DRAKE, C., and JONES, W., 2018. Costs of occupational ill-health in construction [online]. Available from: https://www.ice.org.uk/ICEDevelopmentWebPortal/media/Documents/Disciplines and Resources/Briefing Sheet/Costs-of-occupational-ill-health-in-constructionformattedFINAL.pdf [Accessed 21 Jan 2019].

GIBSON, J., 2002. Revitalising Health and Safety in Construction [online]. [online]. Available from: http://www.hse.gov.uk/consult/disdocs/dde20.pdf [Accessed 8 Jan 2019].

GILLEN, M., RADNOFF, D., CAPICIK, L., SCHILL, J., EPSTIEN, B., SCHNEIDER, S., FESS, S., SKRABAK, J., 
MAHONEY, S., WARREN, H., and MCINNIS, J., 2019. Focus Four for Health Guidance Document [online]. Falls Church, VA. Available from: https://www.aiha.org/government-

affairs/PositionStatements/FocusFour-forHealth_GuidanceDocument.pdf [Accessed 22 Jul 2019].

GIROGIO, M.-T., 2018. The different occupational health services in France - Atousante - Health at work in France. AtouSante.com Health at work in France [online]. Available from:

https://www.atousante.com/en/occupational-health-services-france/ [Accessed 25 Feb 2019].

HALL, D.A., FACKRELL, K., LI, A.B., THAVAYOGAN, R., SMITH, S., KENNEDY, V., TINOCO, C., RODRIGUES, E.D., CAMPELO, P., MARTINS, T.D., LOURENÇO, V.M., RIBEIRO, D., and HAIDER, H.F., 2018. A narrative synthesis of research evidence for tinnitus-related complaints as reported by patients and their significant others. Health and Quality of Life Outcomes [online]. 16 (1), p. 61. Available from: https://hqlo.biomedcentral.com/articles/10.1186/s12955-018-0888-9 [Accessed 14 Nov 2018].

HANDFORD, M., LEPINE, K., BOCCIA, K., RUDDICK, F., ALYEKSYEYEVA, D., THOMPSON, A., HOLNESS, D.L., and SWITZER-MCINTYRE, S., 2017. Hand-arm vibration syndrome: Workers' experience with functional impairment and disability. Journal of Hand Therapy [online]. 30 (4), pp. 491-499. Available from: https://www.sciencedirect.com/science/article/pii/S089411301630182X [Accessed 14 Nov 2018].

HARTVIGSEN, J., HANCOCK, M.J., KONGSTED, A., LOUW, Q., FERREIRA, M.L., GENEVAY, S., HOY, D., KARPPINEN, J., PRANSKY, G., SIEPER, J., SMEETS, R.J., UNDERWOOD, M., BUCHBINDER, R., HARTVIGSEN, J., CHERKIN, D., FOSTER, N.E., MAHER, C.G., UNDERWOOD, M., VAN TULDER, M., ANEMA, J.R., CHOU, R., COHEN, S.P., MENEZES COSTA, L., CROFT, P., FERREIRA, M., FERREIRA, P.H., FRITZ, J.M., GENEVAY, S., GROSS, D.P., HANCOCK, M.J., HOY, D., KARPPINEN, J., KOES, B.W., KONGSTED, A., LOUW, Q., ÖBERG, B., PEUL, W.C., PRANSKY, G., SCHOENE, M., SIEPER, J., SMEETS, R.J., TURNER, J.A., and WOOLF, A., 2018. What low back pain is and why we need to pay attention. The Lancet [online]. 391 (10137), pp. 2356-2367. Available from:

https://www.sciencedirect.com/science/article/pii/S014067361830480X\#bib103 [Accessed 14 Nov 2018].

HOLMES, N., LINGARD, H., YESILYURT, Z., and DE MUNK, F., 1999. An Exploratory Study of Meanings of Risk Control for Long Term and Acute Effect Occupational Health and Safety Risks in Small Business Construction Firms. Journal of Safety Research [online]. 30 (4), pp. 251-261. Available from: https://www.sciencedirect.com/science/article/pii/S0022437599000201 [Accessed 8 Jan 2019].

HSE, 2005. Constructing Better Health Report of baseline employer survey [online]. [online]. Available from: http://www.hse.gov.uk/research/rrpdf/rr381.pdf [Accessed 15 Jan 2019].

HSE, 2016. Costs to Britain of Work-Related Cancer [online]. Available from: www.nationalarchives.gov.uk/doc/open-government-licence/, [Accessed 8 Jan 2019].

HSE, 2018a. Construction statistics in Great Britain [online]. [online]. Available from: http://www.hse.gov.uk/statistics/industry/construction.pdf [Accessed 3 Jan 2019].

HSE, 2018b. Costs to Britain of workplace fatalities and self-reported injuries and ill health, 2016/17 [online]. [online]. Available from: http://www.hse.gov.uk/statistics/cost.htm.

HSE, 2019. Construction health risks: Key points - Managing occupational health risks in construction [online]. [online]. Available from: http://www.hse.gov.uk/construction/healthrisks/key-points.htm [Accessed 13 Mar 2019].

JÄRVHOLM, B., STATTIN, M., ROBROEK, S.J.W., JANLERT, U., KARLSSON, B., and BURDORF, A., 2014. Heavy work and disability pension - a long term follow-up of Swedish construction workers. Scandinavian journal of work, environment \& health [online]. 40 (4), pp. 335-42. Available from: 
http://www.ncbi.nlm.nih.gov/pubmed/24385007 [Accessed 8 Jan 2019].

KING, N., 2004. Using templates in the thematic analysis of text. In: C. CASSELL and G. SYMON, eds.

Essential Guide to Qualitative Methods in Organizational Research. London: Sage Publications. pp. 256-270.

KRAMER, D.M., BIGELOW, P.L., CARLAN, N., WELLS, R.P., GARRITANO, E., VI, P., and PLAWINSKI, M., 2010. Searching for needles in a haystack: Identifying innovations to prevent MSDs in the construction sector. Applied Ergonomics [online]. 41 (4), pp. 577-584. Available from: https://www.sciencedirect.com/science/article/pii/S000368700900163X [Accessed 11 Jan 2019].

KWON, B.K., ROFFEY, D.M., BISHOP, P.B., DAGENAIS, S., and WAI, E.K., 2011. Systematic review: occupational physical activity and low back pain. Occupational Medicine [online]. 61 (8), pp. 541-548. Available from: https://academic.oup.com/occmed/article-lookup/doi/10.1093/occmed/kqr092 [Accessed 14 Nov 2018].

LANGDON, R.R. and SAWANG, S., 2018. Construction Workers' Well-Being: What Leads to Depression, Anxiety, and Stress? Journal of Construction Engineering and Management [online]. 144 (2), p. 04017100. Available from: http://ascelibrary.org/doi/10.1061/\%28ASCE\%29C0.1943-7862.0001406 [Accessed 23 Nov 2018].

LE, B.E.R., AY, Y., and AYERS, B., 2010. An Interpretative Phenomenological Analysis of the Psychological Ramifications of Hand-Arm Vibration Syndrome. Journal of Health Psychology www.sagepublications.com [online]. 15 (4), pp. 533-542. Available from: www.sagepublications.com [Accessed 11 Jan 2019].

LINGARD, H. and TURNER, M., 2015. Improving the health of male, blue collar construction workers: a social ecological perspective Improving the health of male, blue collar construction workers: a social ecological perspective. Construction Management and Economics [online]. 33 (No 1), pp. 18-34. Available from: http://www.tandfonline.com/action/journalInformation?journalCode=rcme20 [Accessed 23 Nov 2018].

LINGARD, H. and TURNER, M., 2017. Promoting construction workers' health: a multi-level system perspective. Construction Management and Economics [online]. 35 (5), pp. 239-253. Available from: http://www.tandfonline.com/action/journallnformation?journalCode=rcme20http://dx.doi.org/10.10 80/01446193.2016.1274828 [Accessed 22 Nov 2018].

MARCHAND, A. and BLANC, M.-E., 2010. The contribution of work and non-work factors to the onset of psychological distress: An eight-year prospective study of a representative sample of employees in Canada. Journal of Occupational Health [online]. 52 (3), pp. 176-185. Available from: http://www.scopus.com/inward/record.url?eid=2-s2.077956921030\&partnerID=40\&md5=82d5007e9a7080e57757caca704daab1.

MATES, 2019. Construction Worker Suicide Prevention - MATES In Construction [online]. [online]. Available from: http://matesinconstruction.org.au/ [Accessed 13 Mar 2019].

MATES IN MIND, 2019. Mates in Mind - Let's gets construction talking [online]. [online]. Available from: https://www.matesinmind.org/ [Accessed 13 Mar 2019].

MAZUREK, J.M., WOOD, J.M., SCHLEIFF, P.L., and WEISSMAN, D.N., 2017. Surveillance for Silicosis Deaths Among Persons Aged 15-44 Years - United States, 1999-2015. MMWR. Morbidity and mortality weekly report [online]. 66 (28), pp. 747-752. Available from:

http://www.ncbi.nlm.nih.gov/pubmed/28727677 [Accessed 10 Oct 2018].

VAN DER MOLEN, H.F., DE VRIES, S.C., STOCKS, S.J., WARNING, J., and FRINGS-DRESEN, M.H.W., 2016. 
Incidence rates of occupational diseases in the Dutch construction sector, 2010-2014. Occupational and environmental medicine [online]. 73 (5), pp. 350-2. Available from:

http://www.ncbi.nlm.nih.gov/pubmed/26940576 [Accessed 11 Jan 2019].

NEBOSH, 2019. National General Certificate in Occupational Health and Safety - NEBOSH [online]. [online]. Available from: https://www.nebosh.org.uk/qualifications/national-general-certificate/ [Accessed 18 Mar 2019].

NIOSH, 1989. Occupational exposure to hand-arm vibration Criteria for a recommended standard. [online]. Available from: https://www.cdc.gov/niosh/docs/89-106/89-106.pdf?id=10.26616/NIOSHPUB89106 [Accessed 8 Jan 2019].

OSHA, 2017. Occupational Safety and Health Administration Commonly Used Statistics [online]. [online]. Available from: https://www.osha.gov/oshstats/commonstats.html [Accessed 13 Mar 2019].

PANOPOULOS, G.D. and BOOTH, R.T., 2007. An analysis of the business case for safety: the costs of safetyrelated failures and the costs of their prevention. Policy and Practice in Health and Safety [online]. 5 (1), pp. 61-73. Available from: http://www.tandfonline.com/doi/full/10.1080/14774003.2007.11667688 [Accessed 21 Jan 2019].

PÉREZ-ALONSO, A., ANTONIO CÓRDOBA-DOÑA, J., LUIS MILLARES-LORENZO, J., FIGUEROA-MURILLO, E., GARCÍA-VADILLO, C., ROMERO-MORILLO, J., ROMERO, J., and ANTONIO CÓ RDOBA-DOÑA, J., 2014. Outbreak of silicosis in Spanish quartz conglomerate workers. International Journal of Occupational and Environmental Health [online]. 20 (1), pp. 26-32. Available from:

http://www.tandfonline.com/action/journalInformation?journalCode=yjoh20 [Accessed 10 Oct 2018].

PINDER, J., GIBB, A., DAINTY, A., JONES, W., FRAY, M., and HARTLEY, R., 2016. Engagement of smaller organisations in occupational safety and health. In: R. DINGWALL and S. FROST, eds. Health and Safety in a changing world [online]. Routledge. pp. 117-130. Available from: https://www.taylorfrancis.com/books/e/9781317371922/chapters/10.4324\%2F9781315672021-15 [Accessed 21 Jan 2019].

PINTO, A., NUNES, I.L., and RIBEIRO, R.A., 2011. Occupational risk assessment in construction industryOverview and reflection. Safety Science [online]. 49 (5), pp. 616-624. Available from: https://www.sciencedirect.com/science/article/pii/S0925753511000051 [Accessed 21 Jan 2019].

QUINN, P.S., WELCH, L., RINGEN, K., DEMENT, J., BINGHAM, E., and DONG, X.S., 2014. Risks of a lifetime in construction. Part II: Chronic occupational diseases. American Journal of Industrial Medicine [online]. 57 (11), pp. 1235-1245. Available from: http://doi.wiley.com/10.1002/ajim.22366 [Accessed 8 Jan 2019].

RANTANEN, J., LEHTINEN, S., and LAVICOLI, S., 2013. Occupational health services in selected International Commission on Occupational Health (ICOH) member countries. Scandinavian Journal of Work, Environment \& Health [online]. Available from: https://www.jstor.org/stable/23558254 [Accessed 13 Mar 2019].

RANTANEN, J., LEHTINEN, S., VALENTI, A., and IAVICOLI, S., 2017. A global survey on occupational health services in selected international commission on occupational health (ICOH) member countries. BMC Public Health [online]. 17 (1), p. 787. Available from: http://bmcpublichealth.biomedcentral.com/articles/10.1186/s12889-017-4800-z [Accessed 13 Mar 2019].

REVEALING REALITY, 2018. Work-related Musculoskeletal Disorders, a tri-sector exploration [online]. Available from: http://www.hse.gov.uk/research/insight/msd-report.pdf [Accessed 8 Jan 2019]. 
SAFE WORK AUSTRALIA, 2017. Mid- term review of the Australian work health and safety strategy 2012 2022 [online]. Canberra: Safe Work Australia. Available from:

https://www.safeworkaustralia.gov.au/system/files/documents/1711/mid-term-review-of-theaustralian-work-health-and-safety-strategy_1.pdf.

SEN, D., 2015. Working with asbestos and the possible health risks. Occupational Medicine [online]. 65 (1), pp. 6-14. Available from: https://academic.oup.com/occmed/articlelookup/doi/10.1093/occmed/kqu175 [Accessed 10 Oct 2018].

SHERRATT, F., 2015. Legitimizing public health control on sites? A critical discourse analysis of the Responsibility Deal Construction Pledge. Construction Management and Economics [online]. 33 (5-6), pp. 444-452. Available from:

http://www.tandfonline.com/action/journallnformation?journalCode=rcme20 [Accessed 23 Nov 2018].

SHERRATT, F., 2018. Shaping the discourse of worker health in the UK construction industry. Construction Management and Economics [online]. 36 (3), pp. 141-152. Available from: https://www.tandfonline.com/doi/full/10.1080/01446193.2017.1337916 [Accessed 14 Jan 2019].

SOUSA, V., ALMEIDA, N.M., and DIAS, L.A., 2015. Risk-based management of occupational safety and health in the construction industry - Part 2: Quantitative model. Safety Science [online]. 74, pp. 184-194. Available from: https://www.sciencedirect.com/science/article/pii/S0925753515000041 [Accessed 11 Jan 2019].

STEFFENS, D., FERREIRA, M.L., LATIMER, J., FERREIRA, P.H., KOES, B.W., BLYTH, F., LI, Q., and MAHER, C.G., 2015. What Triggers an Episode of Acute Low Back Pain? A Case-Crossover Study. Arthritis Care \& Research [online]. 67 (3), pp. 403-410. Available from: http://doi.wiley.com/10.1002/acr.22533 [Accessed 14 Nov 2018].

STOCKS, S.J., MCNAMEE, R., CARDER, M., and AGIUS, R.M., 2010. The incidence of medically reported workrelated ill health in the UK construction industry. Occupational and environmental medicine [online]. 67 (8), pp. 574-6. Available from: http://www.ncbi.nlm.nih.gov/pubmed/20647381 [Accessed 10 Oct 2018].

STOCKS, S.J., TURNER, S., MCNAMEE, R., CARDER, M., HUSSEY, L., and AGIUS, R.M., 2011. Occupation and work-related ill-health in UK construction workers. Occupational Medicine [online]. 61 (6), pp. 407415. Available from: https://academic.oup.com/occmed/article-lookup/doi/10.1093/occmed/kqr075 [Accessed 10 Oct 2018].

SVEDSATER, H., HILTON, E., PATEL, C., MACEY, J., ROBERTS, J., and BRADSHAW, L., 2016. Qualitative Interviews and Focus Groups with COPD and Asthma Patients: Understanding Patient Burden, Life Impact and Treatment Preferences. American Journal of Respiratory and Critical Care Medicine. p. 193.

TAM, V.W.Y. and FUNG, I.W.H., 2008. A Study of Knowledge, Awareness, Practice and Recommendations Among Hong Kong Construction Workers on Using Personal Respiratory Protective Equipment at Risk. The Open Construction and Building Technology Journal [online]. 2 (1), pp. 69-81. Available from: https://benthamopen.com/contents/pdf/TOBCTJ/TOBCTJ-2-69.pdf [Accessed 11 Jan 2019].

THABIT, H., BURNS, N., SHAH, S., BREMA, I., CROWLEY, V., FINNEGAN, F., DALY, B., and NOLAN, J.J., 2013. Prevalence and predictors of diabetes and cardiometabolic risk among construction workers in Ireland: The Construction Workers Health Trust screening study. Diabetes and Vascular Disease Research [online]. 10 (4), pp. 337-345. Available from: https://journals.sagepub.com/doi/pdf/10.1177/1479164113479808 [Accessed 8 Jan 2019]. 
TOWNSEND, K., LOUDOUN, R., and MARKWELL, K., 2016. The role of line managers in creating and maintaining healthy work environments on project construction sites The role of line managers in creating and maintaining healthy work environments on project construction sites. Construction Management and Economics [online]. 34 (9), pp. 611-621. Available from: http://www.tandfonline.com/action/journallnformation?journalCode=rcme20 [Accessed 23 Nov 2018].

TYERS, C. and HICKS, B., 2012. Occupational health provision on the Olympic Park and athletes' village: Final report [online]. Available from: http://www.hse.gov.uk/research/rrpdf/rr921.pdf.

TYERS, C., SINCLAIR, A., LUCY, D., COWLING, M., GORDON-DSEAGU, V., and RICK, J., 2007. Constructing Better Health Final Evaluation Report RR565 [online]. Available from:

http://www.hse.gov.uk/research/rrpdf/rr565.pdf [Accessed 15 Jan 2019].

VIESTER, L., VERHAGEN, E.A.L.M., BONGERS, P.M., and VAN DER BEEK, A.J., 2018. Effectiveness of a Worksite Intervention for Male Construction Workers on Dietary and Physical Activity Behaviors, Body Mass Index, and Health Outcomes: Results of a Randomized Controlled Trial. American Journal of Health Promotion [online]. 32 (3), pp. 795-805. Available from: http://journals.sagepub.com/doi/10.1177/0890117117694450 [Accessed 20 Feb 2019].

WANG, X., DONG, X.S., CHOI, S.D., and DEMENT, J., 2017. Work-related musculoskeletal disorders among construction workers in the United States from 1992 to 2014. Occupational and environmental medicine [online]. 74 (5), pp. 374-380. Available from: http://www.ncbi.nlm.nih.gov/pubmed/28039200 [Accessed 8 Jan 2019].

WANG, Y. and GRIFFIS, F., 2018. The Theory of Zero Incident Safety Management. Journal of Civil, Construction and Environmental Engineering [online]. 3 (3), pp. 83-98. Available from: http://www.sciencepublishinggroup.com/j/jccee [Accessed 14 Jan 2019].

WATERMAN, L., 2007. The Future for Occupational Health in the United Kingdom. Policy and Practice in Health and Safety [online]. 5, pp. 125-140. Available from: http://www.tandfonline.com/action/journallnformation?journalCode=tphs20 [Accessed 23 Nov 2018].

WATERMAN, L., 2018. Wellbeing - stop tossing it bananas. Construction News [online]. Available from: https://www.constructionnews.co.uk/10035491.article?utm_source=newsletter\&utm_medium=email \&utm_campaign $=C N \_E d i t o r i a l N e w s l e t t e r s . R e g:$ Send - Editors Picks\&mkt_tok=eyJpljoiTORNeVpUUTBNRGMOT1RWaSIsInQiOilyZONHQ3hOREtHY2FIWWFjSjVrMGdnQ 250M25HU2pIR3hES [Accessed 23 Nov 2018].

WEST, G.H., DAWSON, J., TEITELBAUM, C., NOVELLO, R., HUNTING, K., and WELCH, L.S., 2016. An analysis of permanent work disability among construction sheet metal workers. American Journal of Industrial Medicine [online]. 59 (3), pp. 186-195. Available from: http://doi.wiley.com/10.1002/ajim.22545 [Accessed 8 Jan 2019].

WHO, 1994. Global strategy on occupational health for all: The way to health at workrecommendation of the Second Meeting of the WHO Collaborating Centres in Occupational Health, 11-14 October 1994, Beijing, China (No. WHO/OCH/95.1. Unpublished) [online]. WHO. Geneva: World Health Organization. Available from: https://www.who.int/occupational_health/publications/globstrategy/en/index5.html [Accessed 13 Mar 2019].

WILKINS, J.R., 2011. Construction workers' perceptions of health and safety training programmes. Construction Management and Economics [online]. 29 (10), pp. 1017-1026. Available from: http://www.tandfonline.com/doi/abs/10.1080/01446193.2011.633538 [Accessed 18 Mar 2019]. 
WORKSAFE NEW ZEALAND, 2016. Healthy Work Worksafe's Strategic Plan for Work-Related Health 20162026 [online]. [online]. Available from: https://www.worksafe.govt.nz/worksafe/informationguidance/work-related-health/documents-and-images/wrh-strategic-plan-healthy-work-20162026.pdf.

ZWETSLOOT, G., LEKA, S., and KINES, P., 2017. Vision zero: from accident prevention to the promotion of health, safety and well-being at work. Policy and Practice in Health and Safety [online]. 15 (2), pp. 88100. Available from: https://www.tandfonline.com/doi/full/10.1080/14773996.2017.1308701 [Accessed 14 Jan 2019]. 